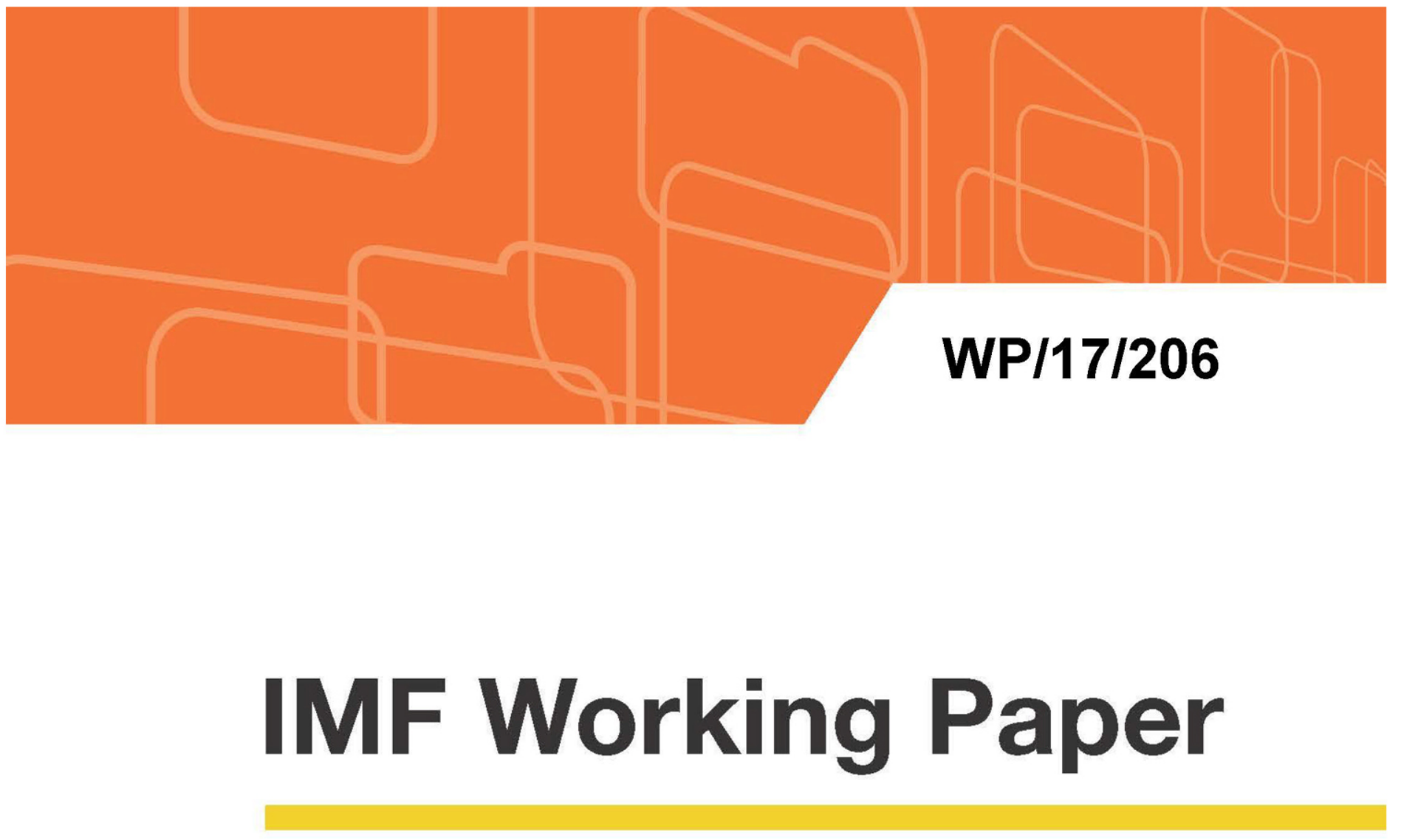

\title{
Did the Exchange Rate Floor Prevent Deflation in the Czech Republic?
}

by Francesca Caselli

IMF Working Papers describe research in progress by the author(s) and are published to elicit comments and to encourage debate. The views expressed in IMF Working Papers are those of the author(s) and do not necessarily represent the views of the IMF, its Executive Board, or IMF management. 


\title{
WP/17/206
}

\section{IMF Working Paper}

\section{Did the Exchange Rate Floor Prevent Deflation in the Czech Republic?}

\author{
by Francesca Caselli
}

IMF Working Papers describe research in progress by the author(s) and are published to elicit comments and to encourage debate. The views expressed in IMF Working Papers are those of the author(s) and do not necessarily represent the views of the IMF, its Executive Board, or IMF management.

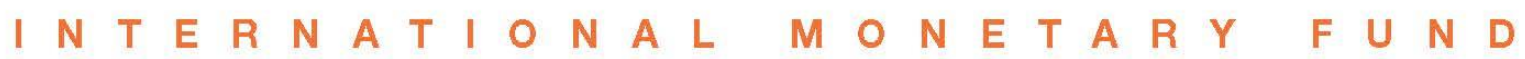




\title{
IMF Working Paper
}

\author{
European Department
}

\section{Did the Exchange Rate Floor Prevent Deflation in the Czech Republic? Prepared by Francesca Caselli}

\author{
Authorized for distribution by Alasdair Scott
}

September 2017

\section{This Working Paper should not be reported as representing the views of the IMF.} The views expressed in this Working Paper are those of the author(s) and do not necessarily represent those of the IMF or IMF policy. Working Papers describe research in progress by the author(s) and are published to elicit comments and to further debate.

\begin{abstract}
To fight deflationary pressures at the zero lower bound, in November 2013, the Czech National Bank (CNB) introduced a one-sided floor on the exchange rate, as an additional monetary policy instrument. This paper investigates the impact of the FX floor on inflation in the Czech Republic, by comparing actual inflation with counterfactuals in the absence of the exchange rate floor. Three different empirical strategies are implemented: an event study, difference-indifference regressions and a synthetic control method. The empirical results provide evidence that the exchange rate floor was effective in fighting deflationary pressures and prevented inflation from going into negative territory. The magnitude of the effect ranges between 0.5 to 1.5 percentage points. The results are robust to different econometric specifications.
\end{abstract}

JEL Classification Numbers: F31; E58

Keywords: Foreign exchange intervention, exchange rate, synthetic control method

Author's E-mail Address: fcaselli@imf.org 
Contents

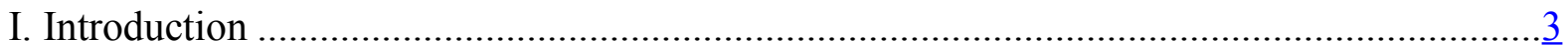

II. The Exchange Rate Tool in the CNB's IT Framework....................................................

III. Data and Stylized Facts...........................................................................................

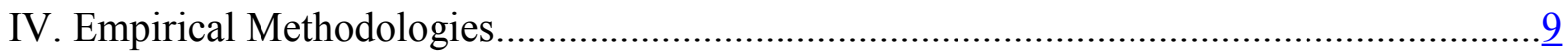

A. An Event Study Approach ………………………………………………... 10

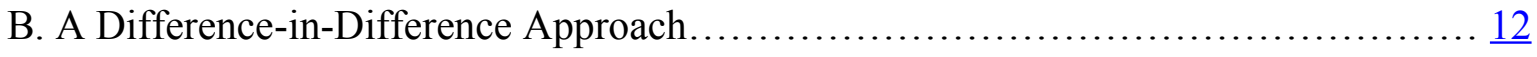

C. A Synthetic Method Approach............................................................................. 20

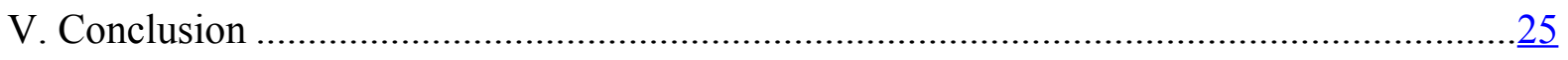

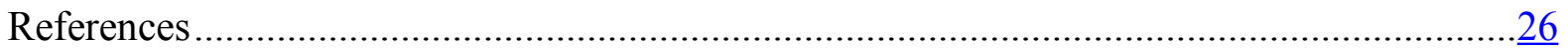

Figures

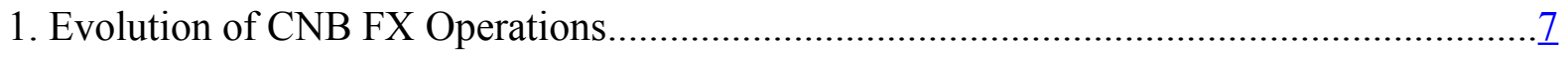

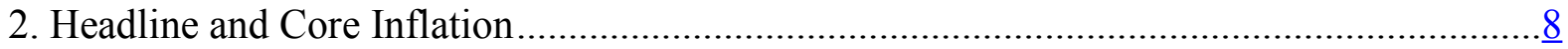

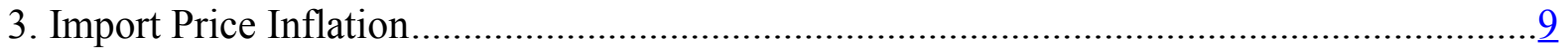

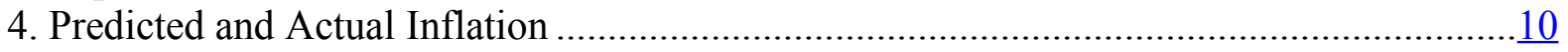

5. Difference Between Predicted and Actual Inflation .......................................................11

6. Predicted and Actual Inflation - Augmented Baseline..................................................

7. Inflation in the Czech Republic vs other Countries ……..............................................

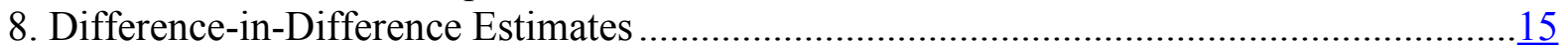

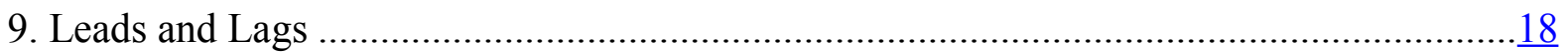

10. Difference-in-Difference Estimation - Core Inflation.................................................... 18

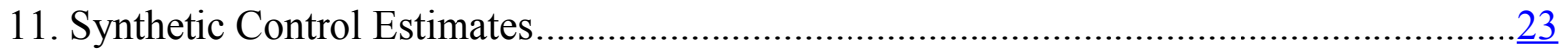

12. Placebo Test for Headline Inflation …………………................................................

13. Synthetic Control for Inflation - Non-EMU Sample......................................................

Tables

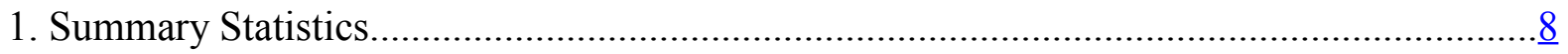

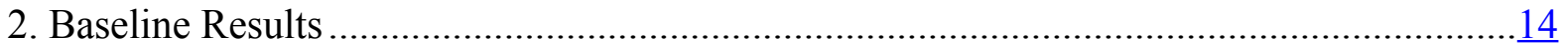

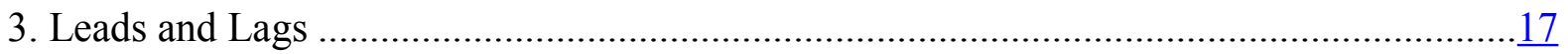

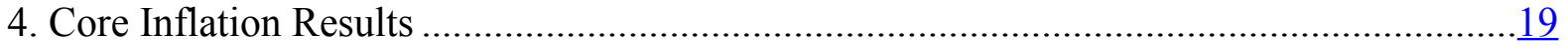

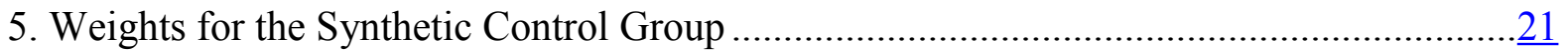

6. Comparison of the Actual and Synthetic Series .............................................................

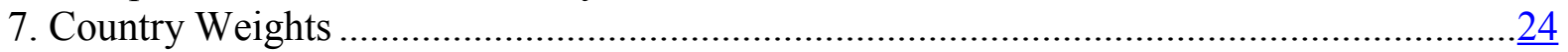

Appendice

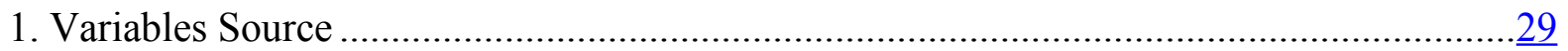




\section{INTRODUCTION}

When the global financial crisis unfolded and monetary policy rates came close to the zero lower bound (ZLB), it became clear that conventional monetary policies were not effective in loosening monetary conditions and supporting demand. Central banks started relying on less traditional instruments, or unconventional monetary policies (UMP), to reach their targets. In the early stages of the crisis, UMP were mainly targeted to restore market functioning, whereas measures to boost economic activity at the ZLB were adopted at later stages. Forward guidance, bonds purchases and negative interest rates are among the policies adopted by several central banks. Foreign exchange rate interventions constituted an alternative tool for small open economies to fight deflationary pressures (Lizal and Schwarz 2014).

In November 2013, after a prolonged recession and hitting the zero lower bound, the Czech National Bank (CNB) decided to use the koruna exchange rate as an additional instrument of inflation targeting to ease monetary conditions, and to avoid deflation. The CNB introduced a one-sided exchange rate floor at a depreciated level of 27 Czech Koruna (CZK) to the euro to fulfill the inflation target, affecting the overall price level through higher import prices and inflation expectations. The adoption of the FX floor, as an additional tool of inflation targeting, is motivated by the literature on monetary policy at the zero lower bound, and particularly by the papers by Krugman (1998) and Svensson (2001). The latter advocates a combination of a price-level target, a devaluation of the currency and a temporary crawling peg to implement Krugman's proposal, i.e. the credible promise by the central bank to be "irresponsible" in order to seek a higher future price level.

In recent years, foreign exchange intervention operations have been implemented by central banks, both in advanced and emerging markets, especially with the objective of coping with large capital inflows. In September 2011, after a period of sharp appreciation, the Swiss National Bank (SNB) set a minimum exchange rate of 1.20 francs to the euro, announcing that it was prepared to buy foreign currency in unlimited quantities. ${ }^{1}$ In August 2013, The Central Bank of Brazil (BCB) announced a program of foreign exchange intervention to cope with the high volatility of the Brazilian real. Since 2008, the Bank of Israel (BOI) has also intervened in the foreign exchange market aiming to smooth excess volatility. The CNB, instead, carried out exchange rate interventions already in the past. Since the adoption of the inflation targeting regime, the CNB has implemented FX interventions in three episodes, often trying to prevent appreciation of the exchange rate. The first intervention period took place between February and July 1998, the second between October 1999 and March 2000, and the third between October 2001 and September 2002 (Lizak, and Schwarz 2014). Gersl and Holub (2006) review the Czech experience with foreign exchange interventions since

\footnotetext{
${ }^{1}$ Wille, Klaus (6 September 2011). "Swiss Pledge Unlimited Currency Purchases". Bloomberg.com. Bloomberg News. Retrieved 18 March 2014.
} 
1998 and find limited impact on the koruna's exchange rate and its volatility. Dominguez et al. (2013) study the impact of Czech reserves sales targeted to limit value losses of Eurodenominated assets and find evidence of an effect on the exchange rate level, only when sales are implemented on a daily basis.

This paper analyzes whether the introduction of the exchange rate floor had managed in avoiding deflationary pressures in the Czech Republic. The question we want to answer is "what would have been the level of inflation if the CNB did not announce the exchange rate floor?" The analysis is complicated by the fact that we do not observe the counterfactual for the Czech inflation in the absence of the policy intervention. To overcome this problem, three empirical strategies, that aim at building a suitable counterfactual, are adopted.

- As a starting point, we implement an event study around the time of the announcement of the floor. A standard New Keynesian Phillips curve for the Czech Republic is estimated on the pre-event sample and the forecasts subsequently used to measure the behavior of inflation due to the intervention.

- We then investigate the effect of the adoption of the floor on different measures of inflation in a difference-in-difference framework. We test whether headline and core inflation in the Czech Republic behave differently after November 2013 with respect to inflation in a control group of similar European countries. We also test for anticipatory effects and we document dynamic patterns of the effect. We estimate different specifications with multiple sets of fixed effects to ensure that omitted variables are controlled for.

- Given the difficulties in constructing a good control group, we implement the methodology developed by Abadie et al. (2010) and we build a synthetic control group as a weighted average of other unaffected countries. This method focuses on the construction of a synthetic control group by searching for a combination of other units that are selected to match as close as possible the characteristics of the country affected by the treatment.

We find that the introduction of the FX floor worked in the desired direction, preventing headline inflation to go into negative territory. The result is robust across the three different methodologies and several robustness checks. The magnitude of the impact varies between 0.5 and 1.5 percentage points. We also find some evidence that the exchange rate floor had an impact on core inflation. ${ }^{2}$

\footnotetext{
${ }^{2}$ Other studies adopting this methodology include Billmeier and Nannicini (2013) who study the effect of economic liberalization, Cavallo et al. (2013) who assess the effect of natural disasters on economic growth and Heilmann (2016) who studies whether economic conflict hurts trade.
} 
In general, the empirical evidence on the effectiveness of exchange rate interventions is relatively mixed. ${ }^{3}$ Older contributions, often focusing on advanced economies, find limited impact of FX interventions (Dominguez and Frankel (1990), Ghosh (1992), etc.). Motivated by the increased volatility in capital flows following the global crisis and the subsequent large exchange rate movements, a recent strand of the literature has been focusing on the so called macroeconomic management motive of foreign exchange rate intervention (Blanchard et al. 2015), with respect to the more traditional precautionary motive, to build-up liquidity as insurance against future shocks. ${ }^{4}$ Blanchard et al. 2015 exploit the exogenous character of capital inflows to a small open economy and estimate the response of foreign exchange intervention and other macro-variables with a VAR. Adler et al. (2015), in a panel setting and using instrumental variables, find evidence the interventions significantly affect the level of the exchange rate. In an earlier contribution, Adler and Tovar (2011) examines sterilized foreign exchange interventions in Latin America and confirm their effectiveness in mitigating appreciation pressures. Daude et al. (2014), using an error correction model, find that interventions are, on average, effective in moving the real exchange rate in the desired direction. Other papers try to break the contemporaneous relationship between exchange rate fluctuations and foreign exchange interventions using high frequency data. Fatum and Pedersen (2009) study the real-time effects of sterilized FX intervention using intraday intervention data from the Danish central bank. Rincon and Toro (2011) and Kamil (2008) estimate the effect of interventions on daily data in Colombia. Chamon et al. (2015) are the first to use synthetic control methods to investigate whether FX intervention in Brazil have been successful in mitigating depreciations pressures. Brůha and Tonner (2017) study the effect of the FX floor on the Czech economy with the official DSGE model of the CNB and different variants of the synthetic control method. They find that the introduction of the floor prevented core inflation to fall into negative territory, whereas the effect on other macro variables, while positive, is not statistically significant.

In this paper, we follow a similar empirical strategy to that of Chamon et al. (2015), but we complement the analysis with a difference-in-difference estimation and several robustness checks. Moreover, we believe that the Czech experience constitutes an interesting case study per se, because of the nature of the exchange rate commitment that has been one-sided and at a depreciated exchange rate level. The paper is structured as follows. Section 2 reviews the Czech experience with the exchange rate floor within the inflation targeting regime, Section

\footnotetext{
${ }^{3}$ For a comprehensive review of the literature see Sarno and Taylor (2001) and Menkhoff (2013).

${ }^{4}$ The effect of interventions with a precautionary scope are well established in the literature (Ghosh, Ostry and Tsangarides, 2012; Jeanne and Ranciere, 2011; Aizenaman and Lee, 2008). Theoretical contributions on the macroeconomic management motive of foreign exchange rate interventions include: Benes et al. (2013), who extends a standard inflation targeting NewKeynesian small-open-economy model including foreign exchange rate interventions. Their framework incorporates "hybrid" IT regimes that include managed floats or crawling pegs, in which FX interventions can help insulate the economy against certain shocks, especially those to international financial conditions. Adler et al. (2016) finds that the optimal magnitude of intervention is higher in monetary policy regimes with lower uncertainty. Cavallino (2016) investigates the desirability of foreign exchange intervention in response to currency misalignments with a New Keynesian model of a small open economy and imperfect financial markets.
} 
3 presents the data and Section 4 discusses the empirical models and results. Section 5 concludes.

\section{THE EXCHANGE RATE TOOL IN THE CNB'S IT FRAMEWORK}

In November 2012, after a prolonged recession, the CNB brought its policy rate to technical zero ( 0.05 percent). However, this measure seemed to be insufficient to bring inflation back to its target. In November 2013 the central bank decided that further monetary easing was needed to boost growth. Quantitative easing through government bond purchases had little scope, since banks were already experiencing surpluses in long-term liquidity. Similarly, qualitative easing did not seem an appropriate solution given the small market for riskier securities in the country. ${ }^{5}$ For these reasons the CNB decided to introduce a one-sided exchange rate floor at CZK 27 to the euro to depreciate the currency and offset deflationary risks. On November 7, 2013, the CNB made the following statement: "The Bank Board also decided to start using the exchange rate as an additional instrument for easing the monetary conditions. The CNB will intervene on the foreign exchange market to weaken the koruna so that the exchange rate of the koruna against the euro is close to CZK 27". The CNB allows the exchange rate to freely float on the weaker side of the FX floor. The FX interventions to support the commitment are implemented without the need for an additional decision of the CNB Board.

Given permanent deflationary pressures, in several subsequent occasions the FX floor horizon was extended. On December 172013 the Bank Board communicated that the CNB would keep the exchange rate close to CZK 27/EUR at least until the start of 2015. The CNB communicated that it would exit this unconventional regime once inflation is back to its desired target. On December 172014 the CNB communicated that it would not discontinue the use of the exchange rate as a monetary policy instrument before $2016 .{ }^{6} \mathrm{At}$ its most recent meeting on February 2 2017, the Bank Board confirmed that the CNB would not discontinue the use of the exchange rate as a monetary policy instrument before the second quarter of 2017. The Bank Board confirmed the CNB's commitment to intervene on the foreign exchange market, if needed, to weaken the currency so that the exchange rate of the koruna is kept close to CZK 27 to the euro. The extension of the exchange rate floor was justified by inflation forecasts that will sustainably fulfil the 2 percent target in the first half of this year. ${ }^{7}$

Crucial to this "augmented" inflation targeting framework is the communication strategy adopted by the CNB. The key ingredient to successfully guide inflation expectations, without de-anchoring long-term expectations, is that the exchange rate tool is perceived as a temporary instrument (Alichi et al. 2015). The immediate reaction of the public to the

\footnotetext{
${ }^{5}$ See Franta et al. (2014) and Alichi et al. (2015).

${ }^{6}$ The shift of the hard-commitment until the end of 2015 had been communicated already at the end of July 2014.

${ }^{7} \underline{\text { https://www.cnb.cz/en/monetary_policy/bank_board_minutes/2017/170202 prohlaseni.html. }}$
} 
introduction of the floor was mostly critical. The change in policy was seen as unexpected and as a source of uncertainty for the corporate and financial sector. The CNB had to change its communications strategy providing details on monetary policy decisions to the public on the day following the monetary policy meeting. ${ }^{8}$

Figure 1. Evolution of CNB FX Operations

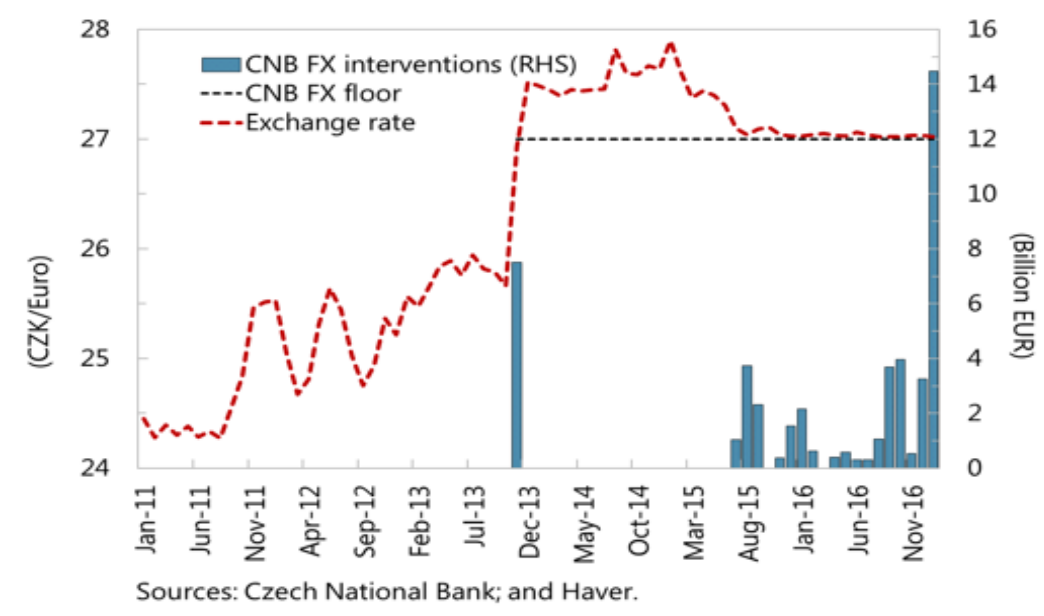

Figure 1 shows the exchange rate path and FX interventions by the CNB since 2011. The day of the announcement, the exchange rate of the Czech koruna with the euro moved from 25.8 to close to 27 right after the announcement of the floor, trading at the end of the day at almost exactly 27. Interventions in the FX market have been limited since November 2013, but the Koruna has been strengthening and moving close to the floor in recent years. Starting in the summer of 2015, a strengthening of the koruna coincided with higher interventions.

\section{DATA AND STYLIZED FACTS}

The empirical analysis is based on the estimation of an open-economy new Keynesian Phillips curve, in which the standard inflation-unemployment relationship is augmented to account for imported inflation. The specification of the empirical model builds on Iossifov and Podpiera (2014), who show that food and energy prices, together with taxes and movements in administered prices have an important role in explaining headline inflation across CESEE non-euro countries since 2011. They also find that disinflation in the euro area significantly impacted countries with an exchange-rate target and inflation targeters that have a high share of foreign value added in their domestic demand. In their empirical model, imported inflation is decomposed into the impact of the nominal effective exchange rate, world food and oil prices, and core inflation in the euro area. The sample includes 14

\footnotetext{
${ }^{8}$ These communications improvements include: written statement by the Bank Board published after the press conference on the day of the monetary policy meeting, a summary of the Inflation report published the day after the Board meeting, a dedicated page to the exchange rate commitment on the CNB website, etc.
} 
countries from 2006Q1 to 2015Q3. ${ }^{9}$ Table 1 presents the summary statistics for the sample including the Czech Republic. All variables are expressed in 12-month growth rates. Inflation is computed using the Harmonized Indices of Consumer Prices (HICP) published by Eurostat. Commodity price changes are captured by world oil and food price indices in US dollars multiplied by the weights of energy and food in the consumer baskets. The cyclical unemployment rate is extracted with the Baxter-King bandpass filter. The impact of taxes and administered prices is captured by their contribution to headline inflation. Inflation expectations are at one-year horizon. Price pressures from the euro area are proxied by euro area core inflation multiplied by the share of foreign value added in domestic demand.

Table 1. Summary Statistics

\begin{tabular}{lccccc}
\hline Variable & Obs. & Mean & Std. Dev. & Min & Max \\
\hline Headline inflation & 585 & 0.028 & 0.028 & -0.039 & 0.175 \\
Core inflation & 585 & 0.019 & 0.020 & -0.049 & 0.111 \\
Oil price & 585 & 0.009 & 0.045 & -0.089 & 0.150 \\
Food price & 585 & 0.009 & 0.045 & -0.089 & 0.150 \\
Unemployment gap & 585 & -0.001 & 0.014 & -0.049 & 0.062 \\
Administered prices & 585 & 0.007 & 0.007 & -0.014 & 0.042 \\
Taxes & 585 & 0.005 & 0.009 & -0.030 & 0.060 \\
Inflation expectations - 1 year ahead & 495 & 0.025 & 0.012 & -0.023 & 0.091 \\
Core inflation in the EA & 585 & 0.005 & 0.002 & 0.001 & 0.013 \\
\hline
\end{tabular}

Figure 2. Headline and Core Inflation

(in percent)

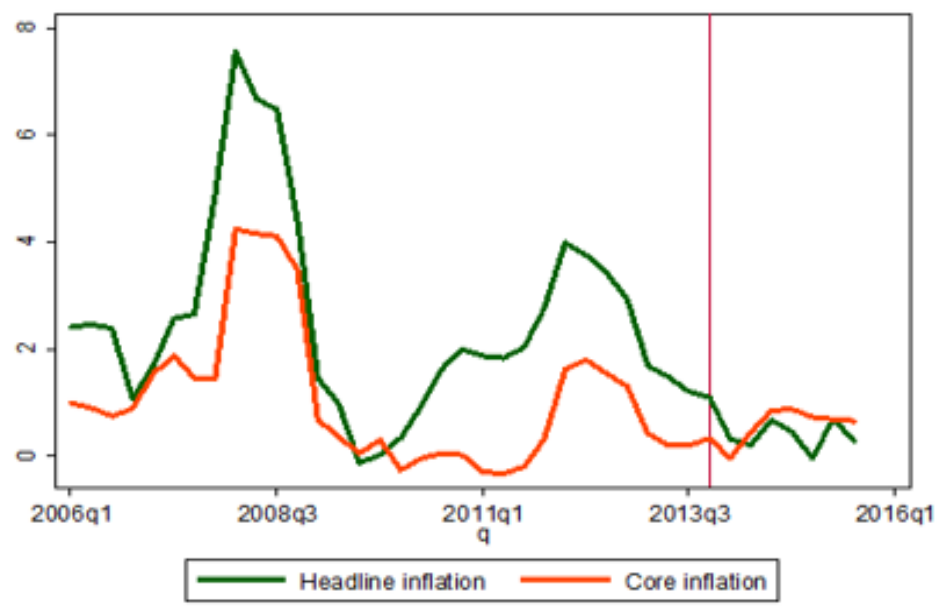

Note: The green line plots headline inflation and the orange line core inflation. The red vertical line corresponds to the introduction of the FX floor. Both series are from Eurostat.

\footnotetext{
${ }^{9}$ For more details on sources and construction of the variables see Iossifov and Podpiera (2014) and the Appendix. The sample includes: Bulgaria, Croatia, Czech Republic, Denmark, Estonia, Hungary, Latvia, Lithuania, Poland, Romania, Slovakia, Slovenia, Sweden and the United Kingdom.
} 
Figure 2 plots headline and core inflation for the Czech Republic and shows that both series reverted their downward trend after the introduction of the floor. However, headline inflation has been moving very close to zero since the beginning of 2015. Interestingly, import price inflation presents a clear upward trend after the introduction of the floor, giving a first indication that the new policy might have worked through higher price of imports (Figure $3) .^{10}$

Figure 3. Import price inflation (in percent)

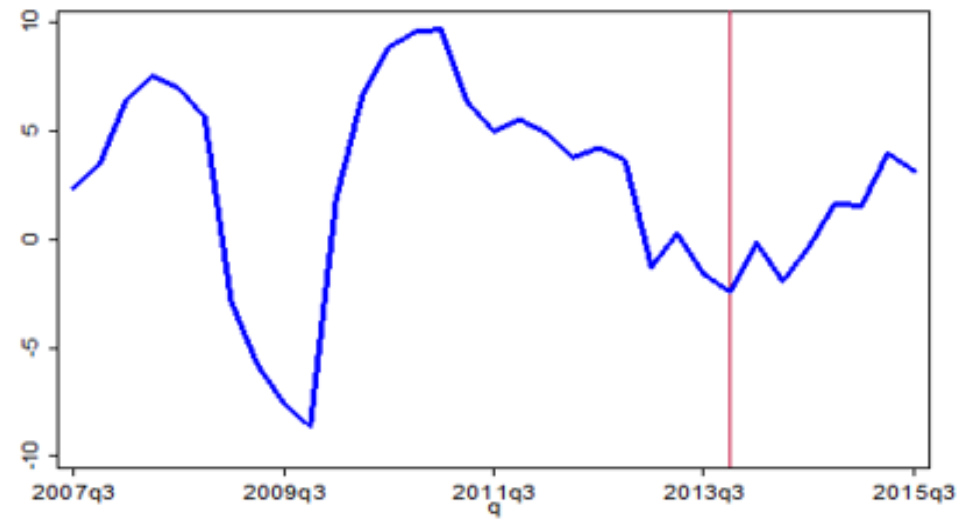

Note: The blue line plots import price inflation core from the Czech Statistical Office. The red vertical line corresponds to the introduction of the FX floor.

\section{EMPIRICAL METHODOLOGIES}

The question we want to answer in the empirical section is: what would have been the level of the Czech inflation in the absence of the FX floor? The analysis is complicated by the fact that we do not observe the counterfactual and given the difficulties in building a good control group when macro policies are involved, we adopt three different empirical strategies.

- An event study that uses the pre-intervention sample to build a model to forecast inflation in the absence of the FX floor;

- A difference-in-difference regression analysis that compares the evolution of inflation in the Czech Republic with a control group of similar countries; and

- A synthetic control method that exploits the statistical proprieties of the data to choose a control group that best matches the pre-treatment characteristics of the treated country.

\footnotetext{
${ }^{10}$ Import prices are from the Czech Statistical Office, downloaded through Haver Analytics.
} 


\section{A. An Event Study Approach}

We start the empirical analysis with a simple approach the aims at measuring the behavior of inflation due to the policy change. More specifically, we estimate the following regression on the pre-intervention sample.

$\pi_{t}=\alpha+\beta \pi_{t-1}+\gamma \pi_{t-2}+\delta_{\text {oil }}+\theta$ food $_{t}+\phi u_{t}+\lambda a d \min _{t}+\mu \operatorname{tax}_{t}+v \pi \exp _{t}+$ $\psi E A \pi_{t}+\epsilon_{t}$

where $\pi_{t}$ is Czech headline inflation, oil $t$ and food $_{t}$ are world oil and food prices respectively, multiplied by the Czech Republic's share of energy and food in the CPI basket, $u_{t}$ is the unemployment gap, $a_{d m i n}$ and $\operatorname{tax}_{t}$ are the contribution of taxes and administered prices to headline inflation respectively, and $E A \pi_{t}$ is the Euro Area core inflation weighted by the share of foreign value added in domestic demand. ${ }^{11}$ With respect to the baseline model in Iossifov and Podpiera (2014), we omit the nominal exchange rate since it is directly impacted by the policy intervention. ${ }^{12}$

Figure 4. Predicted and Actual Inflation

(in percent)

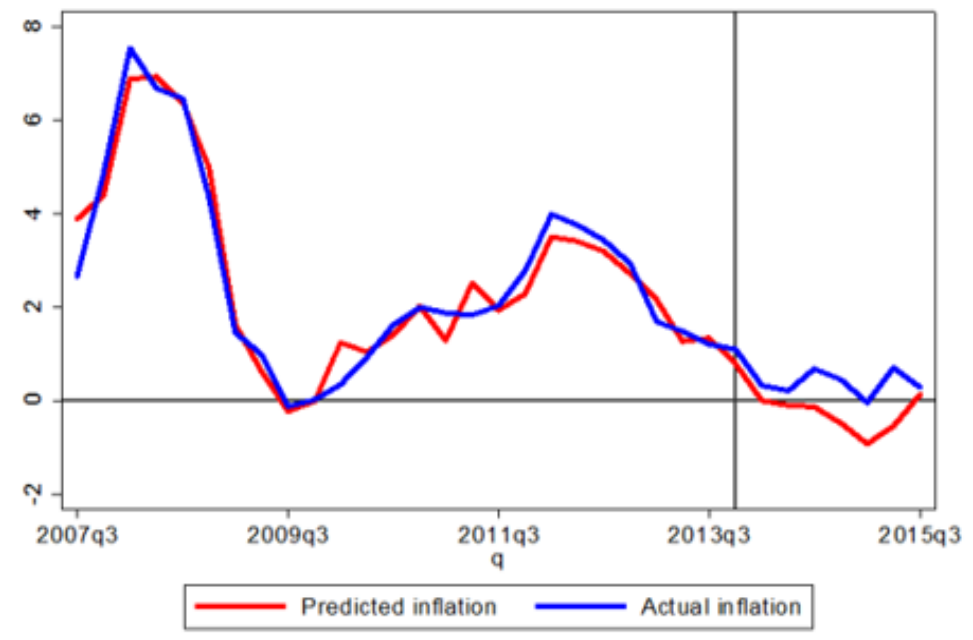

Note: The blue line plots actual headline inflation in the Czech Republic and the red line plots the precited values from the New Keynesian Phillips curve estimated up to the introduction of the floor. The black vertical line corresponds to the introduction of the FX floor.

\footnotetext{
11 The unemployment gap is given by the cyclical component of the unemployment rate extracted with the Baxter-King bandpass filter (see Iossifov and Podpiera 2014).

${ }^{12}$ For consistency with the model estimated with difference-in-difference regression and synthetic control we omit the exchange rate, which is the objective of the policy intervention. As mentioned in Campos et al. (2014), the choice of the pretreatment characteristics should include variables that can approximate the path of the treated country, but should not include variables that anticipate the effects of the intervention. As a robustness, however, we augment the baseline with the rate of depreciation of the exchange rate and the results are very much in line with what we obtain omitting the exchange rate.
} 
We estimate this model over the sample up to 2013Q4 (excluded), the time of the introduction of the floor and we obtain predicted values for inflation..$^{13}$ The latter describe the behavior of inflation in the absence of the policy change. The regression has an R-squared of 0.91 , showing a relatively good fit.

The results suggest that the introduction of the floor might have helped in keeping inflation above zero. Figure 4 contrasts the time series of inflation with the predicted value obtained from the previous regression. We observe that, after the introduction of the floor, the two series diverge, with the forecast trending down into negative territory. This suggests that, without the introduction of the policy, inflation would have moved into negative territory However, the difference between the predicted and actual inflation is rather small. Figure 5 shows this metric and the corresponding confidence intervals (at 90, 95 and 99 percent) and we observe that the effect of the introduction becomes significant towards the beginning of 2015 (with a 95 percent confidence interval). This is some suggestive but not conclusive evidence that the exchange rate floor worked in the desired direction to offset deflation risks. As a robustness, we augment the baseline with the nominal exchange rate. The results are shown in Figure 6. Inflation in the absence of the FX floor trends into negative territory, confirming the previous finding.

Figure 5. Difference Between Predicted and Actual Inflation (in percent)

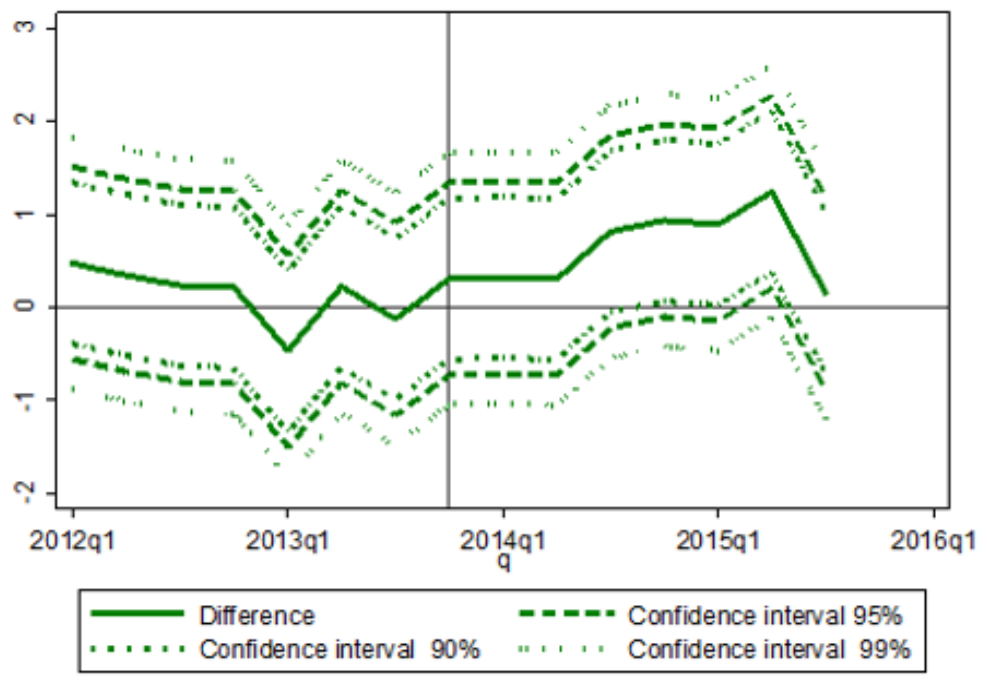

Note: The solid green line reports the difference between the predicted and actual headline inflation. The dashed and dotted lines plot different confidence intervals around the estimates.

${ }^{13}$ The sample starts in 2007Q3. 
Figure 6. Predicted and Actual Inflation - Augmented Baseline (in percent)

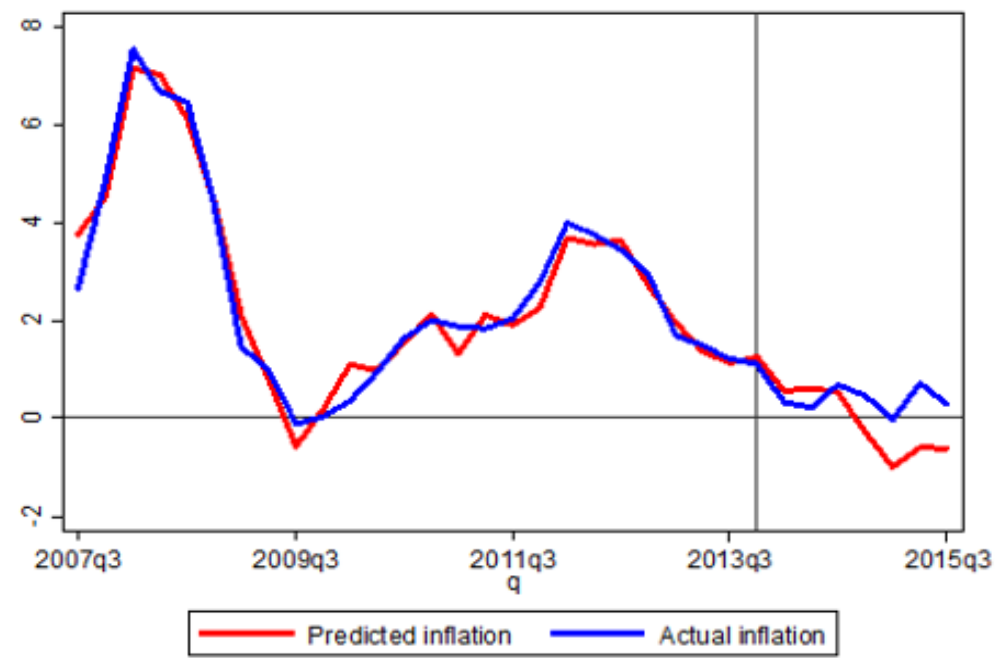

Note: The blue line plots actual headline inflation in the Czech Republic and the red line plots the predicted values of the New Keynesian Phillips curve estimated up to the introduction of the floor and augmented with the nominal exchange rate. The black vertical line corresponds to the introduction of the FX floor.

\section{B. A Difference-in-Difference Approach}

In this section, we adopt a difference-in-difference methodology, which is well suited to estimate the impact of a policy change on a treated group i.e. a group exposed to a certain policy. A simple way to evaluate the effect of a policy is to compare outcomes before and after the intervention for a group affected by the change (Treated Group) to a group not affected by the change (Control Group). ${ }^{14} Y_{C Z E}$ denotes inflation in Czech Republic (the treated country) and $Y_{i}$ inflation in another country, not affected by the policy intervention (the control group). The DD estimate $\left(\delta_{D D}\right)$ of the effect of the introduction of the exchange rate floor in Czech Republic is:

$$
\delta_{D D}=\left(Y_{\text {CZEpost }}-Y_{\text {CZEpre }}\right)-\left(Y_{\text {controlpost }}-Y_{\text {controlpre }}\right)
$$

where pre and post denotes periods before and after the introduction of the floor, respectively. The difference in difference (or "double difference") estimator is defined as the difference in the average outcome in the treatment group before and after the treatment minus the difference in the average outcome in the control group before and after treatment. The difference-in-difference (DD) estimate is an unbiased estimate of the effect of the policy changes if, absent the policy change, the average changes in $Y_{C Z E}-Y_{i}$ would have been the same for treatment and controls. This is equivalent to saying that the treated and the control

\footnotetext{
${ }^{14}$ See for instance Angrist J. D. and Pischke J. S (2009).
} 
group should follow parallel paths before the intervention. We first check this assumption by plotting the evolution of inflation in the Czech Republic vis-à-vis the average inflation in the rest of the countries in the sample.

Inflation in the Czech Republic and in the control group followed parallel trends before the introduction of the exchange rate floor (Figure 7). This is even true if we restrict the analysis to the period after the global financial crisis. This stylized fact is supportive of the idea that the countries we choose might form a good control group to study the policy introduction in a difference-in-difference framework. We will also control more formally for pre-treatment parallel trends in the regression analysis. Another interesting point that emerges from Figure 7 is that average inflation in the control group has been lower than in Czech Republic after 2013Q4, the date of the introduction of the exchange rate floor. This provides evidence in support of the hypothesis that the introduction of the exchange rate floor might have prevented inflation from going into negative territory. ${ }^{15}$

We will now test this hypothesis by estimating the following equation.

$\pi_{i t}=\alpha+\pi_{t-1}+\pi_{t-2}+\beta X_{i t}+\lambda_{i}+\gamma_{t}+\delta T R E A T_{i} * P_{O S T}+\epsilon_{i t}$

where $T R E A T_{i}$ is a dummy variable indicating the Czech Republic and $P O S T_{t}$ is a dummy indicating quarters from 2013Q4 onwards. ${ }^{16}$ The DD estimate is given by the coefficient $\delta$ that captures the effect of the introduction of the exchange rate floor on inflation. The vector $X_{i t}$ includes the control variables used in the previous estimation. Table 2 and Figure 8 presents the results of different specifications. We also introduce different sets of fixed effects and we restrict the analysis to non-Euro Area countries since we want to exclude countries that introduced similar policies (an exchange rate peg) during the sample period. ${ }^{17}$ We cluster the standard errors at the country level to allow for correlated shocks as suggested by Bertrand et al. (2004). The specifications with country and time fixed effects (Column 1 and 2) should be considered as conservative, since they identify the effect of the policy change exploiting within country variation, controlling for global shocks. As robustness, we explicitly include in the regressions pre-intervention country-specific time trends countryspecific time trends (Column 3 to 6) to control for the parallel-trend assumption.

\footnotetext{
${ }^{15}$ According to the CPI compiled by the Czech Statistical Office, inflation never moved into negative territory. In the estimation, however, Eurostat's HICP was employed to ensure comparability across countries. This latter series show a slightly negative value in $2015 \mathrm{q} 1$, equal to -.000273 .

16 The dummies TREAT $T_{i}$ and $P O S T_{t}$ are captured by fixed effects and therefore not included in the estimation.

${ }^{17}$ The fixed effects estimation of models with lagged dependent variable can produce biased estimates. The bias (equal to 1/T) is an issue for short panels, but disappears as $T \rightarrow \infty$. In our sample we have $T=39$, so the fixed effects estimator is likely to perform at least as well as many alternatives. To check the robustness of our results, however, we also estimate the baseline model with a GMM estimator with robust standard errors. The coefficient of the on the interaction is equal to 0.07 , consistent with the fixed effects estimation. Fixed effects results with dynamic panels are generally downward biased.
} 
Table 2. Baseline Results

\begin{tabular}{|c|c|c|c|c|c|c|}
\hline VARIABLES & $\begin{array}{c}(1) \\
\text { Inflation }\end{array}$ & $\begin{array}{c}(2) \\
\text { Inflation }\end{array}$ & $\begin{array}{c}\text { (3) } \\
\text { Inflation }\end{array}$ & $\begin{array}{c}(4) \\
\text { Inflation }\end{array}$ & $\begin{array}{c}(5) \\
\text { Inflation }\end{array}$ & $\begin{array}{c}(6) \\
\text { Inflation }\end{array}$ \\
\hline FX floor & $\begin{array}{l}0.005^{*} \\
(0.003)\end{array}$ & $\begin{array}{c}0.007^{* * *} \\
(0.002)\end{array}$ & $\begin{array}{c}0.009 * * * \\
(0.002)\end{array}$ & $\begin{array}{c}0.015^{* * *} \\
(0.003)\end{array}$ & $\begin{array}{c}0.003 \\
(0.002)\end{array}$ & $\begin{array}{c}0.005 \\
(0.003)\end{array}$ \\
\hline Inflation t-1 & $\begin{array}{c}-0.327^{* * *} \\
(0.040)\end{array}$ & $\begin{array}{c}-0.287^{* *} \\
(0.087)\end{array}$ & $\begin{array}{c}-0.318^{* * *} \\
(0.061)\end{array}$ & $\begin{array}{c}-0.275^{* * *} \\
(0.077)\end{array}$ & $\begin{array}{c}-0.356 * * * \\
(0.059)\end{array}$ & $\begin{array}{c}-0.250 * * * \\
(0.067)\end{array}$ \\
\hline Inflation t-2 & $\begin{array}{c}0.937^{* * *} \\
(0.048)\end{array}$ & $\begin{array}{c}0.849 * * * \\
(0.128)\end{array}$ & $\begin{array}{c}0.908 * * * \\
(0.089)\end{array}$ & $\begin{array}{c}0.798^{* * *} \\
(0.109)\end{array}$ & $\begin{array}{c}0.836 * * * \\
(0.097)\end{array}$ & $\begin{array}{c}0.671 * * * \\
(0.107)\end{array}$ \\
\hline Unemployment gap & $\begin{array}{c}-0.098 * * * \\
(0.037)\end{array}$ & $\begin{array}{l}0.160 * \\
(0.070)\end{array}$ & $\begin{array}{c}-0.111 \\
(0.072)\end{array}$ & $\begin{array}{l}0.216 * \\
(0.114)\end{array}$ & $\begin{array}{c}-0.180 * \\
(0.090)\end{array}$ & $\begin{array}{c}0.596 * * \\
(0.187)\end{array}$ \\
\hline Price of oil & $\begin{array}{c}-0.058 \\
(0.044)\end{array}$ & $\begin{array}{c}0.017 \\
(0.058)\end{array}$ & $\begin{array}{c}-0.062 \\
(0.039)\end{array}$ & $\begin{array}{c}0.031 \\
(0.068)\end{array}$ & $\begin{array}{c}0.002 \\
(0.043)\end{array}$ & $\begin{array}{c}0.075 \\
(0.079)\end{array}$ \\
\hline Price of food & $\begin{array}{c}0.062 * * \\
(0.030)\end{array}$ & $\begin{array}{c}0.001 \\
(0.043)\end{array}$ & $\begin{array}{c}0.072 \\
(0.043)\end{array}$ & $\begin{array}{c}0.001 \\
(0.044)\end{array}$ & $\begin{array}{c}0.048 \\
(0.043)\end{array}$ & $\begin{array}{l}-0.038 \\
(0.041)\end{array}$ \\
\hline Inflation expectation & $\begin{array}{c}0.386 * * * \\
(0.055)\end{array}$ & $\begin{array}{c}0.445^{* * *} \\
(0.101)\end{array}$ & $\begin{array}{c}0.387^{* * *} \\
(0.110)\end{array}$ & $\begin{array}{c}0.480^{* * *} \\
(0.111)\end{array}$ & $\begin{array}{c}0.342^{* * *} \\
(0.108)\end{array}$ & $\begin{array}{c}0.313^{* *} \\
(0.115)\end{array}$ \\
\hline Contribution of admin. prices & $\begin{array}{c}0.488 * * * \\
(0.082)\end{array}$ & $\begin{array}{c}0.233^{* * *} \\
(0.067)\end{array}$ & $\begin{array}{c}0.526 * * * \\
(0.111)\end{array}$ & $\begin{array}{c}0.200 \\
(0.116)\end{array}$ & $\begin{array}{c}0.644^{* * *} \\
(0.081)\end{array}$ & $\begin{array}{c}0.438 * * * \\
(0.063)\end{array}$ \\
\hline Contribution of taxes & $\begin{array}{c}0.200 * * * \\
(0.043)\end{array}$ & $\begin{array}{c}0.290 * * * \\
(0.051)\end{array}$ & $\begin{array}{c}0.202^{* * *} \\
(0.043)\end{array}$ & $\begin{array}{c}0.308 * * * \\
(0.040)\end{array}$ & $\begin{array}{c}0.222^{* * *} \\
(0.048)\end{array}$ & $\begin{array}{c}0.419 * * * \\
(0.054)\end{array}$ \\
\hline EA inflation & $\begin{array}{c}-0.209 \\
(0.654)\end{array}$ & $\begin{array}{c}5.264^{* *} \\
(2.196)\end{array}$ & $\begin{array}{l}-0.254 \\
(1.366)\end{array}$ & $\begin{array}{l}7.756 * \\
(3.491)\end{array}$ & $\begin{array}{c}0.983 \\
(1.623)\end{array}$ & $\begin{array}{c}9.911^{* * *} \\
(2.882)\end{array}$ \\
\hline Observations & 462 & 297 & 462 & 297 & 462 & 297 \\
\hline R-squared & 0.952 & 0.937 & 0.954 & 0.941 & 0.960 & 0.952 \\
\hline Number of id & 14 & 9 & 14 & 9 & 14 & 9 \\
\hline Country FE & YES & YES & YES & YES & YES & YES \\
\hline Time FE & YES & YES & YES & YES & YES & YES \\
\hline Pre country spec. TT & NO & NO & YES & YES & NO & NO \\
\hline Country spec. TT & NO & NO & NO & NO & YES & YES \\
\hline Sample & Full & No EMU & Full & No EMU & Full & No EMU \\
\hline
\end{tabular}

The control variables have the expected sign and magnitude. The interaction term is positive and significant across the first four specifications, suggesting that inflation in the Czech Republic has been higher than in the control group after the introduction of the exchange rate floor. The magnitude of the effect varies (between 0.5 to 1.5 percentage points), but in the baseline model (Column1) the coefficient on the interaction term indicates that the introduction of the floor brought inflation up by 0.5 percentage points in Czech Republic with respect to the control group (see Figure 8 for a visual interpretation of the results). This finding suggests than in absence of the floor inflation would have been between 0.5 and 1.5 percentage points lower. 
Figure 7. Inflation in the Czech Republic vs other Countries (in percent)

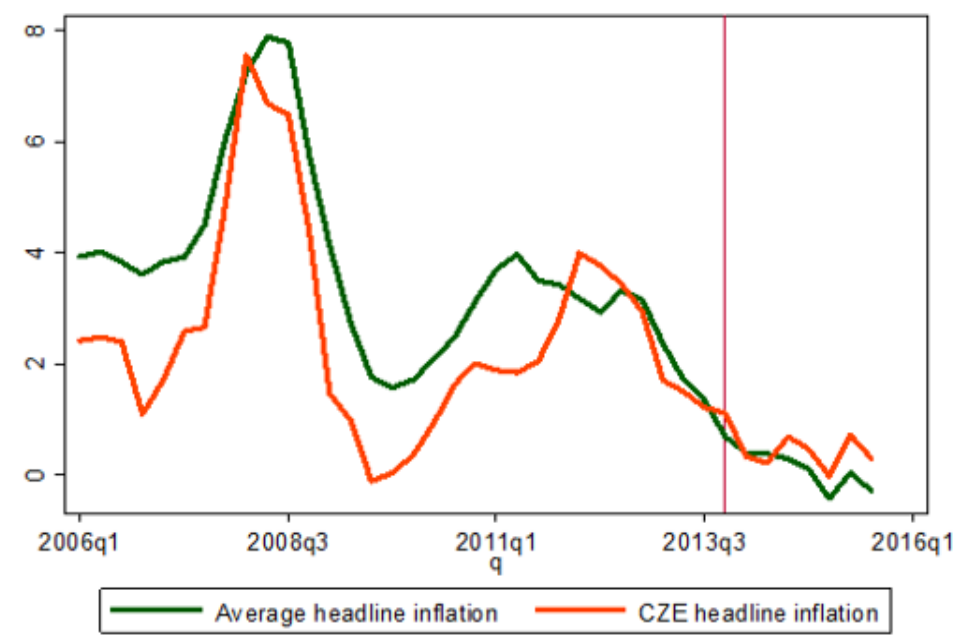

Note: The green line plots the average headline inflation in the sample and the orange line plots headline inflation in the Czech Republic. The red vertical line corresponds to the introduction of the FX floor.

Figure 8. Difference-in-Difference Estimates

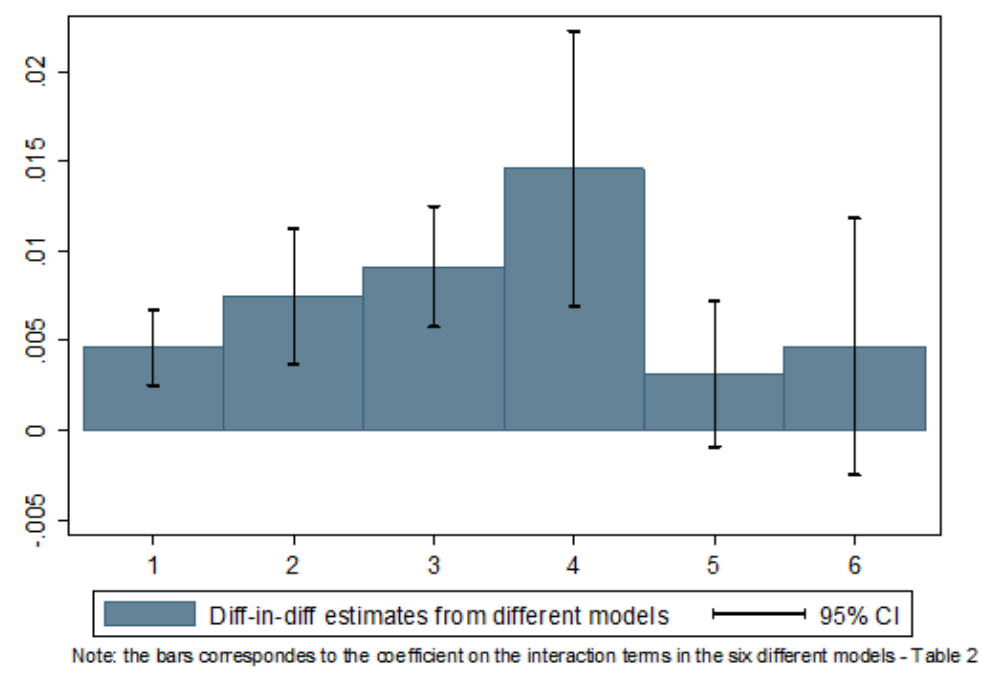

Note: The blue bars report the coefficients on the interaction term (FX floor) from the six different models presented in Table 2. The black lines correspond to 95 percent confidence intervals calculated with clustered standard errors at the country level.

The baseline includes country and quarterly fixed effects to control for unobserved heterogeneity at the country level and for idiosyncratic global shocks, partially reducing concerns of endogeneity. The effect remains significant when we restrict the sample to nonEMU countries (Column 2) to exclude countries that have adopted similar policies to the one of the Czech Republic (Slovakia adopted the euro in 2009, for instance). As a robustness check, Column (3) and (4) explicitly controls for the parallel trend assumption, including pre- 
treatment country specific time trends. The coefficient on the interaction is still positive and significant. Finally, column (5) and (6) show the results of a specification with countryspecific time trends: the effect of the interaction is still positive but not significant. This result might suggest that after the introduction of the floor, countries in the control group and the Czech Republic have been exposed to different shocks and the divergence in inflation path is not only explained by the FX floor. It is also plausible that this specification might be too taxing for country-level data.

A useful exercise, that might help understand whether the observed increase in inflation in the Czech Republic is indeed driven by the introduction of the FX floor and not by other confounding factors, is to test for anticipatory effects. This is easily done introducing in the regression leads of the treatment, as proposed by Autor (2003). ${ }^{18}$ Leads are simple interactions between the time fixed effects at different time horizons relative to the introduction of the floor and the treated country (a dummy equal to one for the Czech Republic). If there are no anticipatory effects of the introduction of the policy change, we would expect all the leads to be insignificant. Adding the lags of the treatment allows instead to trace the dynamic impact of the policy intervention. It is plausible to think that the impact of the exchange rate floor might take some time to materialize.

To test for anticipatory effects, we thus code four lead variables, which take the value 1 only in the four quarters before the floor introduction, and 0 otherwise. For post-FX floor introduction dynamics, we augment the baseline with 4 lag variables that take the value 1 from one quarter after the FX floor introduction to four quarters after the introduction, and 0 otherwise. Figure 9 and Table 3 reports the coefficients on the leads and lags from column 5. We do not observe anticipatory effects when we control for specific time trends (Figure 9 Column 5 and 6 of Table 3), but less conservative specifications show some signs that the introduction of the FX floor has been anticipated. The instability of the results does not come out as a surprise since the CNB started communicating the potential use of the FX floor as early as September 2012. ${ }^{19}$

\footnotetext{
${ }^{18}$ For a similar exercise see also Gehring and Schneider (2015).

${ }^{19}$ Franta et al. (2014)
} 
Table 3. Leads and Lags

\begin{tabular}{|c|c|c|c|c|c|c|}
\hline VARIABLES & $\begin{array}{c}(1) \\
\text { Inflation }\end{array}$ & $\begin{array}{c}(2) \\
\text { Inflation }\end{array}$ & $\begin{array}{c}\text { (3) } \\
\text { Inflation }\end{array}$ & $\begin{array}{c}(4) \\
\text { Inflation }\end{array}$ & $\begin{array}{c}\text { (5) } \\
\text { Inflation }\end{array}$ & $\begin{array}{c}(6) \\
\text { Inflation }\end{array}$ \\
\hline FX floor $t-4$ & $\begin{array}{l}0.002^{*} \\
(0.001)\end{array}$ & $\begin{array}{c}0.002 \\
(0.003)\end{array}$ & $\begin{array}{l}-0.002 \\
(0.002)\end{array}$ & $\begin{array}{l}-0.004 \\
(0.003)\end{array}$ & $\begin{array}{l}-0.001 \\
(0.002)\end{array}$ & $\begin{array}{l}-0.006 \\
(0.004)\end{array}$ \\
\hline FX floor $t-3$ & $\begin{array}{c}0.002 \\
(0.002)\end{array}$ & $\begin{array}{c}0.002 \\
(0.003)\end{array}$ & $\begin{array}{l}-0.003 \\
(0.002)\end{array}$ & $\begin{array}{l}-0.005 \\
(0.005)\end{array}$ & $\begin{array}{c}-0.002 \\
(0.003)\end{array}$ & $\begin{array}{l}-0.007 \\
(0.005)\end{array}$ \\
\hline FX floor $t-2$ & $\begin{array}{c}0.009 * * * \\
(0.002)\end{array}$ & $\begin{array}{c}0.010^{* * *} \\
(0.003)\end{array}$ & $\begin{array}{l}0.003^{*} \\
(0.002)\end{array}$ & $\begin{array}{c}0.003 \\
(0.003)\end{array}$ & $\begin{array}{c}0.003 \\
(0.002)\end{array}$ & $\begin{array}{c}0.001 \\
(0.004)\end{array}$ \\
\hline FX floor t-1 & $\begin{array}{c}0.003 \\
(0.002)\end{array}$ & $\begin{array}{c}0.006 \\
(0.004)\end{array}$ & $\begin{array}{l}-0.003 \\
(0.002)\end{array}$ & $\begin{array}{l}-0.002 \\
(0.003)\end{array}$ & $\begin{array}{c}-0.003 \\
(0.003)\end{array}$ & $\begin{array}{l}-0.003 \\
(0.002)\end{array}$ \\
\hline$F X$ floor $t=0$ & $\begin{array}{c}0.009 * * * \\
(0.001)\end{array}$ & $\begin{array}{c}0.013^{* * *} \\
(0.002)\end{array}$ & $\begin{array}{c}0.003 \\
(0.002)\end{array}$ & $\begin{array}{c}0.005 \\
(0.003)\end{array}$ & $\begin{array}{c}0.003 \\
(0.003)\end{array}$ & $\begin{array}{c}0.003 \\
(0.005)\end{array}$ \\
\hline FX floor $t+1$ & $\begin{array}{l}-0.000 \\
(0.001)\end{array}$ & $\begin{array}{c}0.004 \\
(0.002)\end{array}$ & $\begin{array}{l}0.008^{*} \\
(0.004)\end{array}$ & $\begin{array}{l}0.016^{*} \\
(0.008)\end{array}$ & $\begin{array}{c}-0.001 \\
(0.002)\end{array}$ & $\begin{array}{c}0.001 \\
(0.002)\end{array}$ \\
\hline FX floor $t+2$ & $\begin{array}{c}0.005^{* * *} \\
(0.001)\end{array}$ & $\begin{array}{c}0.008^{* *} \\
(0.002)\end{array}$ & $\begin{array}{c}0.013^{* * *} \\
(0.003)\end{array}$ & $\begin{array}{c}0.020^{* *} \\
(0.007)\end{array}$ & $\begin{array}{c}0.004 \\
(0.003)\end{array}$ & $\begin{array}{c}0.003 \\
(0.004)\end{array}$ \\
\hline FX floor $t+3$ & $\begin{array}{c}0.009^{* * *} \\
(0.002)\end{array}$ & $\begin{array}{c}0.012^{* * *} \\
(0.003)\end{array}$ & $\begin{array}{c}0.017^{* * *} \\
(0.003)\end{array}$ & $\begin{array}{c}0.024^{* * *} \\
(0.007)\end{array}$ & $\begin{array}{c}0.007^{* *} \\
(0.003)\end{array}$ & $\begin{array}{c}0.006 \\
(0.005)\end{array}$ \\
\hline Constant & $\begin{array}{l}-0.000 \\
(0.010)\end{array}$ & $\begin{array}{c}-0.047^{* *} \\
(0.019)\end{array}$ & $\begin{array}{c}0.006 \\
(0.011)\end{array}$ & $\begin{array}{c}-0.052^{*} \\
(0.025)\end{array}$ & $\begin{array}{c}0.012 \\
(0.015)\end{array}$ & $\begin{array}{l}-0.031 \\
(0.025)\end{array}$ \\
\hline Observations & 406 & 261 & 406 & 261 & 406 & 261 \\
\hline R-squared & 0.953 & 0.937 & 0.955 & 0.942 & 0.959 & 0.955 \\
\hline Country FE & YES & YES & YES & YES & YES & YES \\
\hline Time FE & YES & YES & YES & YES & YES & YES \\
\hline Pre country spec. $\Pi \pi$ & NO & NO & YES & YES & NO & NO \\
\hline Country spec. $T$ & NO & NO & NO & NO & YES & YES \\
\hline Sample & Full & No EMU & Full & No EMU & Full & No EMU \\
\hline \multicolumn{7}{|c|}{ Note: Clustered standard errors at the country level in parentheses, ${ }^{* * *} p<0.01,{ }^{* *} p<0.05,{ }^{*} p<0.1}$. \\
\hline \multicolumn{7}{|c|}{ The NO-EMU su-sample excludes Slovakia, Estonia, Lithuania, Latvia and Slovenia } \\
\hline \multicolumn{7}{|c|}{ The dummies TREAT and POST are absorbed by fixed effects. } \\
\hline \multicolumn{7}{|c|}{ Interaction is the product of the TREAT and POST dummies. Control variables are not shown. } \\
\hline
\end{tabular}


Figure 9. Leads and Lags

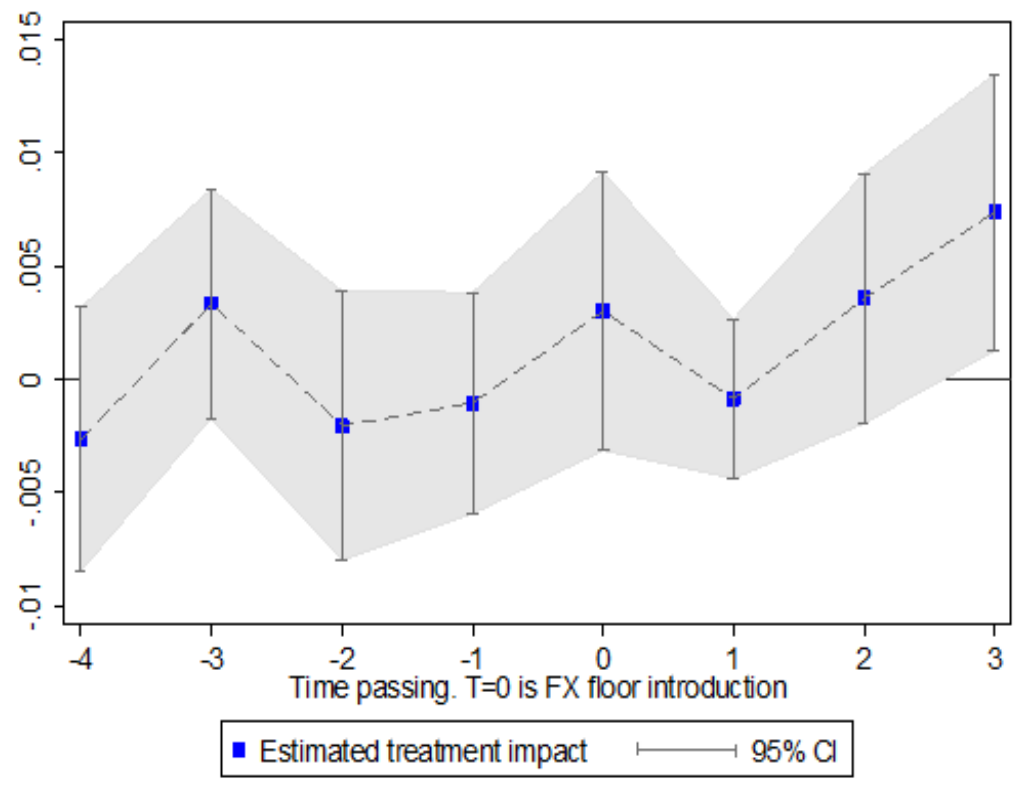

Note: coefficients are from Table 3 Column 5

Note: Regression coefficients and confidence intervals based on Table 3, column 5 . The blue dots indicate the coefficient and the grey-shaded area the 95 percent confidence interval with standard errors clustered at the country level.

Figure 10. Difference-in-Difference Estimation - Core Inflation

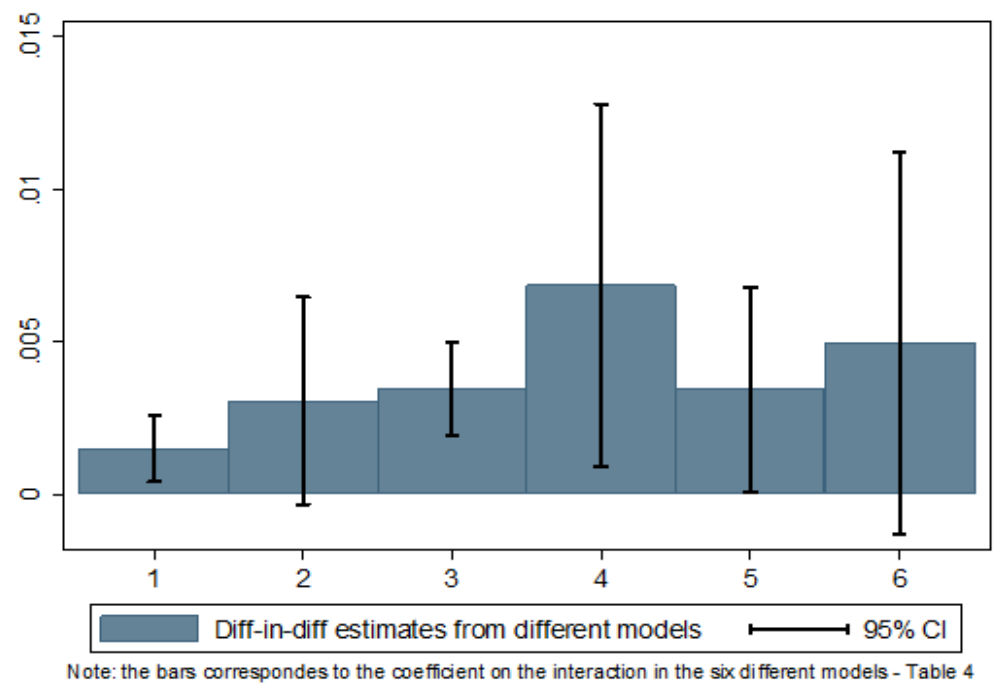

Note: The blue bars plot the coefficients on the interaction term (FX floor) from the six different models presented in Table 4 . The black lines correspond to 95 percent confidence intervals calculated with clustered standard errors at the country level. 
We perform the same exercise using core inflation as the dependent variable. ${ }^{20} \mathrm{We}$ estimate a more parsimonious version of the augmented New Keynesian Phillips curve that excludes volatile components (world oil and food prices, administered prices and the contribution of taxes). This exercise confirms the previous result that the introduction of the floor contributed to prevent disinflation in the Czech Republic. Table 4 and Figure 10 show that the effect of the interaction term is similar in terms of magnitude to the one estimated for headline inflation. The coefficient is significant across the first five specifications with values ranging from 0.1 to 0.6 percentage points.

The different exercises implemented in this section suggest a positive and significant impact on the introduction of the FX floor on both headline and core inflation. The results are generally robust across different specification. As a final step of our analysis we now turn to the synthetic control method estimation to build an alternative control group.

Table 4. Core inflation results

\begin{tabular}{|c|c|c|c|c|c|c|}
\hline \multirow[b]{2}{*}{ VARIABLES } & (1) & (2) & (3) & (4) & (5) & (6) \\
\hline & Core inflation & Core inflation & Core inflation & Core inflation & Core inflation & Core inflation \\
\hline \multirow[t]{2}{*}{ FX floor } & $0.00150^{* *}$ & $0.00306^{*}$ & $0.00346 * * *$ & $0.00685 * *$ & $0.00343 * *$ & 0.00496 \\
\hline & (0.000508) & $(0.00147)$ & $(0.000705)$ & $(0.00257)$ & $(0.00155)$ & $(0.00271)$ \\
\hline \multirow[t]{2}{*}{ Core inflation t-1 } & $1.104 * * *$ & $1.030 * * *$ & $1.085 * * *$ & $0.987 * * *$ & $1.032 * * *$ & $0.937 * * *$ \\
\hline & $(0.0816)$ & $(0.0769)$ & $(0.0840)$ & $(0.0578)$ & (0.0809) & $(0.0635)$ \\
\hline \multirow[t]{2}{*}{ Core inflation t-2 } & $-0.334 * * *$ & $-0.300 * * *$ & $-0.331 * * *$ & $-0.290 * * *$ & $-0.360 * * *$ & $-0.322 * * *$ \\
\hline & $(0.0537)$ & $(0.0403)$ & $(0.0530)$ & $(0.0290)$ & $(0.0586)$ & $(0.0291)$ \\
\hline \multirow[t]{2}{*}{ Unemployment gap } & -0.0553 & 0.0409 & -0.0634 & 0.0474 & $-0.120 * *$ & 0.107 \\
\hline & $(0.0363)$ & $(0.0655)$ & $(0.0446)$ & $(0.0930)$ & $(0.0470)$ & $(0.112)$ \\
\hline \multirow[t]{2}{*}{ Inflation expectation } & $0.291^{* * *}$ & $0.404 * * *$ & $0.296 * * *$ & $0.446^{* * *}$ & $0.265^{* * *}$ & $0.443^{* *}$ \\
\hline & $(0.0630)$ & $(0.117)$ & $(0.0700)$ & $(0.112)$ & $(0.0736)$ & $(0.145)$ \\
\hline \multirow[t]{2}{*}{ EA inflation } & $0.623^{*}$ & 2.428 & 0.714 & 3.559 & $1.796^{*}$ & 3.334 \\
\hline & $(0.308)$ & (1.576) & (0.481) & $(2.465)$ & $(0.907)$ & $(2.681)$ \\
\hline Observations & 462 & 297 & 462 & 297 & 462 & 297 \\
\hline R-squared & 0.939 & 0.915 & 0.941 & 0.919 & 0.946 & 0.926 \\
\hline Number of id & 14 & 9 & 14 & 9 & 14 & 9 \\
\hline Country FE & YES & YES & YES & YES & YES & YES \\
\hline Time FE & YES & YES & YES & YES & YES & YES \\
\hline Pre country spec. $\Pi$ & NO & NO & YES & YES & NO & NO \\
\hline Country spec. Tा & NO & NO & NO & NO & YES & YES \\
\hline Sample & Full & No EMU & Full & No EMU & Full & No EMU \\
\hline \multicolumn{7}{|c|}{ Note: Clustered standard errors at the country level in parentheses, ${ }^{* * *} p<0.01,{ }^{* *} p<0.05,{ }^{*} p<0.1$} \\
\hline \multirow{2}{*}{\multicolumn{7}{|c|}{$\begin{array}{l}\text { The NO-EMU su-sample excludes Slovakia, Estonia, Lithuania, L } \\
\text { The dummies TREAT and POST are absorbed by fixed effects. }\end{array}$}} \\
\hline & & & & & & \\
\hline \multicolumn{7}{|c|}{ FX floor is the product of the TREAT and POST dummies. } \\
\hline
\end{tabular}

${ }^{20}$ Core inflation data are from Eurostat, downloaded through Haver. The countries and time periods are the same as in the previous estimation. 


\section{A Synthetic Method Approach}

As highlighted in the previous section, the common-trend assumption should be validated for the difference-in-difference methodology to work. A crucial element to ensure this assumption is the choice of an appropriate control group. The synthetic control method is a semi-parametric approach that allows to improve on the difference-in-difference in building the right control group. While in a standard difference-in-difference estimation the control group is built as a simple average of the characteristics of similar countries, the synthetic control method uses a weighted average of the set of controls. More specifically, it focuses on the construction of a synthetic control group by searching for a combination of other units that are chosen to match as close as possible the pre-treatment characteristics of the country affected by the intervention.

Abadie et al. (2010) study the effect of California's 1988 tobacco control program on cigarettes' consumption. ${ }^{21}$ They demonstrate that, following the approval of Proposition 99, cigarettes' sales in California dropped significantly relative to a comparable synthetic control region. Suppose we observe $J+1$ region, but only region 1 (California) receives the treatment (i.e. Proposition 99). We observe each region in time periods $t=1, \ldots, T$. Region 1 receives the treatment from period $T_{0}+1$ until time $T$. $Y_{i t}^{I}$ is the outcome of the treated unit $i$ after the treatment at $t \geq T_{0} . Y_{i t}^{N}$ is the potential outcome we would observe for region $i$ at time $t$ if region 1 never receives the treatment. The problem is that we do not observe $Y_{i t}^{N}$ (the counterfactual). If we assume that the treatment has no impact before period $T_{0}+1$, then the average effect on the treated unit is $\alpha_{i t}=Y_{i t}^{I}-Y_{i t}^{N}$. We aim to estimate $\alpha_{1 T_{0}+1}, \ldots, \alpha_{1 T}$. Since $Y_{1 t}^{I}$ is observed we just have to estimate $Y_{1 t}^{N}$. Suppose that $Y_{1 t}^{N}$ is given by the following model:

$$
Y_{\mathrm{i} t}^{N}=\delta_{\mathrm{t}}+\theta_{\mathrm{t}} \mathrm{Z}_{\mathrm{i}}+\lambda_{\mathrm{t}} \mu_{\mathrm{i}}+\epsilon_{\mathrm{it}}
$$

where $\mathrm{Z}_{\mathrm{i}}$ is a vector of observed covariates (not affected by the intervention). Let $W=$ $\left(w_{2}, \ldots, w_{j+1}\right)^{\prime}$ be a $(J X 1)$ vector of positive weights that sum to one. Then any such $W$ represents a potential synthetic control. For a given $W$, the value of the outcome at time $t$ is:

$$
\sum_{j=2}^{J+1} w_{j} y_{j t}=\delta_{t}+\boldsymbol{\theta}_{t} \sum_{j=2}^{J+1} w_{j} \boldsymbol{Z}_{\boldsymbol{i}}+\sum_{j=2}^{J+1} w_{j} \boldsymbol{\mu}_{\boldsymbol{i}}+\sum_{j=2}^{J+1} w_{j} \boldsymbol{\varepsilon}_{\boldsymbol{j} \boldsymbol{t}}
$$

\footnotetext{
${ }^{21}$ Abadie and Gardeazabal (2003) estimate the effects of the terrorist conflict in the Basque Country on the Basque economy using other Spanish regions as a comparison group.
} 
The optimal weights $\boldsymbol{W}^{*}$ satisfy:

$$
\sum_{j=2}^{J+1} w_{j}^{*} y_{j 1}=y_{11}, \quad \sum_{j=2}^{J+1} w_{j}^{*} y_{j 2}=y_{12}, \ldots, \quad \sum_{j=2}^{J+1} w_{j}^{*} y_{j T_{0}}=y_{1 T_{0}} \text { and } \sum_{j=2}^{J+1} w_{j}^{*} z_{j}=Z_{1}
$$

Then we can choose $\mathbf{W}$ to minimize:

$$
\left\|X_{1}-X_{0} \boldsymbol{W}\right\|=\sqrt{\left(X_{1}-X_{0} \boldsymbol{W}\right)^{\prime} V\left(X_{1}-X_{0} \boldsymbol{W}\right)}
$$

We use the previous specification to build a synthetic counterfactual for the Czech inflation in absence of the exchange rate floor. Again we exclude from the estimation the nominal exchange rate since it is the instrument of the policy and therefore it is impacted directly by the treatment. To maximize the fit in the pre-treatment period we tried several specifications. All of them are based on the previous New Keynesian Phillips curve, but the one that shows the best fit includes six quarters of lagged inflation (2009Q3, 2010Q1, 2011Q2, 2012Q1, 2012Q3, 2013Q3). This specification shows a better fit than the one that includes the average of lagged inflation calculated over the whole pre-treatment. The root mean squared error (RMSPE) is 0.007. Inflation prior to the introduction of the exchange rate floor is best replicated by a combination of Denmark, Slovenia and Slovakia (Table 5).

Table 6 compares the pre-treatment characteristics of the actual Czech Republic and the synthetic one. The synthetic series accurately reproduces the values of inflation and its predictors for Czech Republic prior to the treatment (Figure 11). The magnitude of the effect is similar to the one obtained with the difference-in-difference estimation. The introduction of the FX increased headline inflation by between 0.4 and 1.1 percentage points, depending on the time horizon.

Table 5. Weights for the Synthetic Control Group

\begin{tabular}{lr}
\hline Country & Weight \\
\hline BGR & 0 \\
HRV & 0 \\
DNK & 0.108 \\
EST & 0 \\
HUN & 0 \\
LVA & 0.06 \\
LTU & 0 \\
POL & 0 \\
ROU & 0 \\
SVK & 0.154 \\
SVN & 0.679 \\
SWE & 0 \\
GBR & 0 \\
\hline
\end{tabular}


Table 6. Comparison of the Actual and Synthetic Series

\begin{tabular}{lrr}
\hline & \multicolumn{1}{c}{ Treated } & Synthetic \\
\hline Inflation 2009:Q3 & -0.00119 & 0.000939 \\
Inflation 2010:Q1 & 0.003548 & 0.011439 \\
Inflation 2011:Q2 & 0.01843 & 0.025724 \\
Inflation 2012:Q1 & 0.039907 & 0.028069 \\
Inflation 2012:Q3 & 0.034375 & 0.030992 \\
Inflation 2013:Q3 & 0.012184 & 0.017087 \\
Oil price & 0.020653 & 0.02046 \\
Food price & 0.025828 & 0.020999 \\
Unemployment gap & -0.00049 & -0.00092 \\
Contribution of administered prices & 0.009056 & 0.00505 \\
Contribution of taxes & 0.008481 & 0.004049 \\
Inflation expectations & 0.024748 & 0.024924 \\
\hline
\end{tabular}

One of the caveats of the synthetic control method is that it does not provide standard errors to assess whether the results are statistically significant. To overcome this issue, we implement a placebo test to detect wrongful inference. The rationale for placebo experiments is to test whether the estimated impact of the treatment could be driven entirely by chance. Following Abadie et al. (2010), we estimate the same model allowing all the other countries to be treated in 2013Q4. ${ }^{22}$ We would expect, if the control group countries are indeed not affected by the policy change, not to find any large deviations in inflation after the introduction of the floor. In Figure 12 we plot the gap between actual and synthetic inflation for the Czech Republic and all the other "fake" synthetic series. In the pre-treatment sample, the synthetic series displays a relatively good fit, given that the difference between the two series is close to zero. We also notice a positive, but small effect of the introduction of the FX floor on inflation. However, the divergence with respect to other countries is not extreme and some fluctuations of similar magnitude are presents even in the pre-treatment sample. This again suggests the presence of some effect of the FX floor on inflation with relatively small magnitudes, consistent with the results from the event study and the difference-indifference estimation.

\footnotetext{
${ }^{22}$ For a similar approach see also Billmeier and Nannicini, (2013), Chamon et al. (2015), Heilmann (2016), Adhikari et al. (2016) and Swarnali (2016).
} 
Figure 11. Synthetic Control Estimates

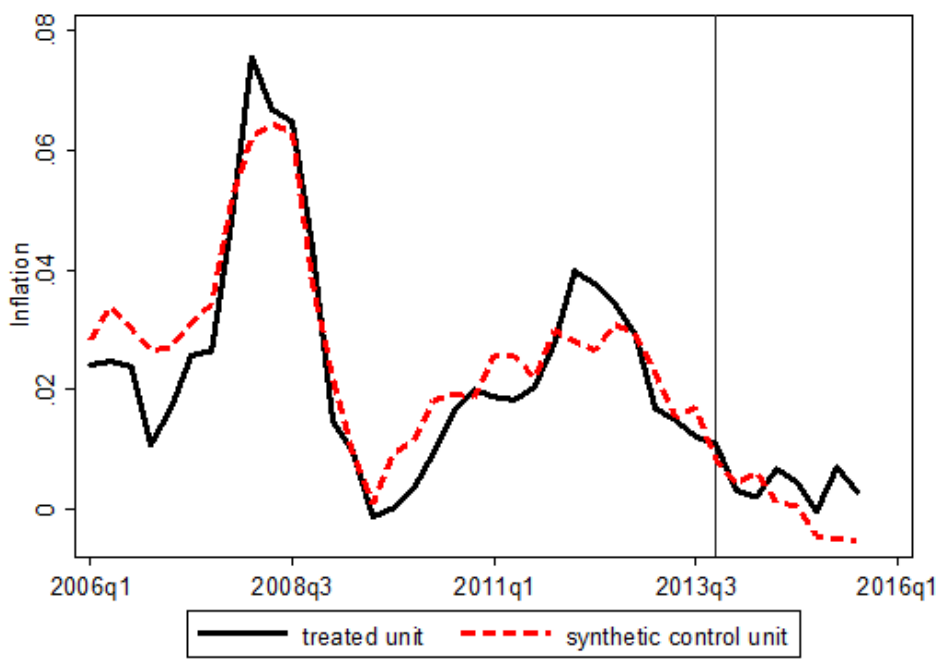

Note: The black line plots headline inflation for the Czech Republic and the red line plots the synthetic control series, which corresponds to inflation in the absence of the FX floor. The black vertical line corresponds to the introduction of the FX floor.

Figure 12. Placebo Test for Headline Inflation

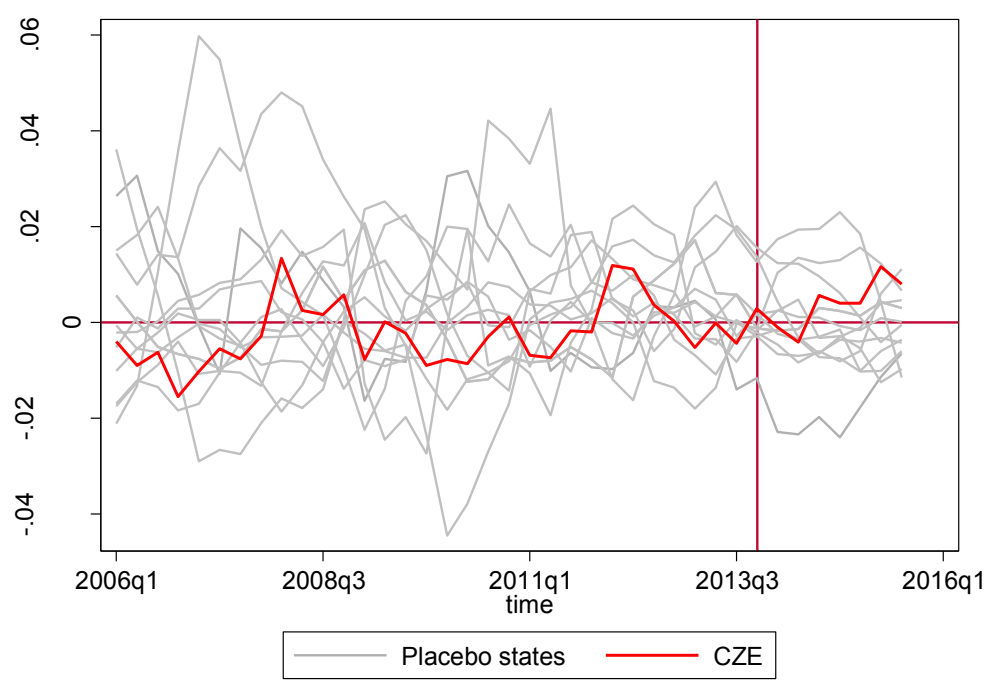

Note: The red line plots the gap in inflation (difference between actual and synthetic inflation) in the Czech Republic. The grey lines plot the same metric for all the others unit treated in the placebo exercise. A positive number corresponds to a positive effect of the introduction of the floor on inflation. The red vertical line corresponds to the introduction of the FX floor. 
Figure 13. Synthetic Control for Inflation - Non-EMU Sample

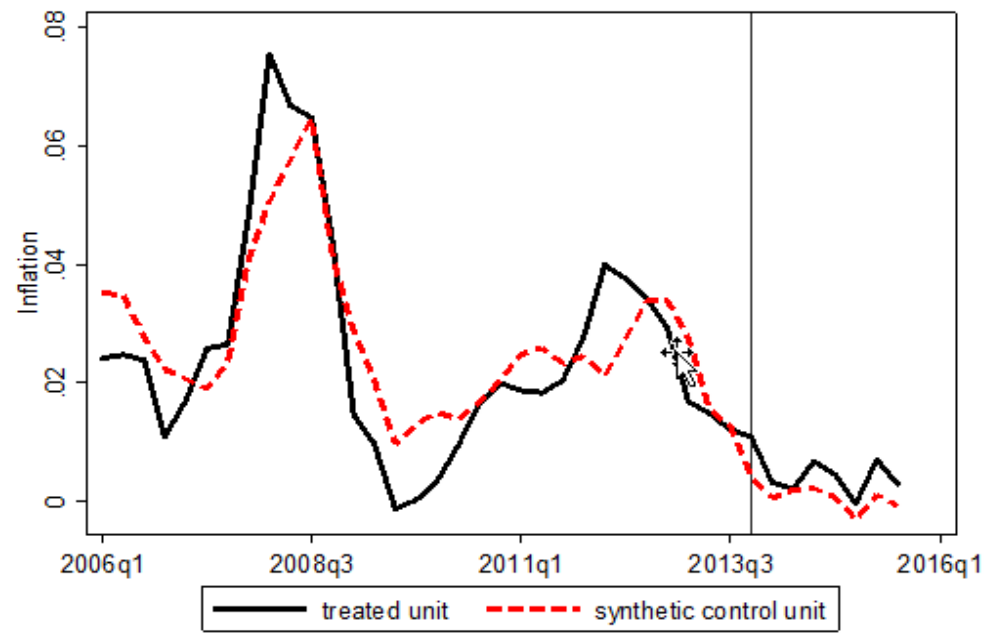

Note: The black line plots headline inflation for the Czech Republic and the red line plots the synthetic control series, which corresponds to inflation in the absence of the FX floor excluding countries in the EMU. The black vertical line corresponds to the introduction of the FX floor.

In a robustness, consistently with the difference-in-diff estimation, we also exclude countries that joined the euro in the estimation period. The rationale is to exclude countries that were affected by similar policies during the estimation sample. A similar pattern to the full sample estimation emerges, however the fit of the synthetic series is poorer (Figure 13). The root mean squared error is still relatively low, equal to 0.009 . The pre-intervention inflation is best reproduced by a combination of Bulgaria, Croatia and Denmark (Table 7).

Table 7. Country weights

\begin{tabular}{lr}
\hline Country & Weight \\
\hline BGR & 0.115 \\
HRV & 0.407 \\
DNK & 0.477 \\
HUN & 0 \\
POL & 0 \\
ROU & 0 \\
SWE & 0 \\
GBR & 0 \\
\hline
\end{tabular}




\section{Conclusion}

To fight deflationary pressures at the zero lower bound, in November 2013, the Czech National Bank introduced a one-sided floor on the exchange rate, as an additional monetary policy instrument. This paper has analyzed the impact of the introduction of the floor on inflation. The question we have been asking is: "what would have been the level of inflation in absence of the policy intervention?". To build a suitable counterfactual, and given the difficulties in estimating treatment effects in macroeconomics, we adopted three different strategies: an event study approach, a difference-in-difference regression and the synthetic control method.

All estimation results suggest that the introduction of the floor prevented Czech inflation from going into negative territory, thus enabling the central bank to achieve the goal of fighting deflationary pressures. The estimated effect is economically and statistically significant for both headline and core inflation with values ranging between 0.5 to 1.5 percentage points. The empirical analysis also supports the idea that the floor had a gradual impact on inflation.

These findings suggest that the CNB policy has been successful in affecting the overall price level through higher import prices and inflation expectations, following Svensson (2001) proposal to escape from a liquidity trap. Further research could explicitly investigate the transmission channels, testing, for instance, the impact of the FX floor on imports and exports prices. 


\section{References}

Abadie, A., A. Diamond, and J. Hainmueller (2010), "Synthetic Control Methods for Comparative Case Studies: Estimating the Effect of California's Tobacco Control Program." Journal of the American Statistical Association, 105(490), 493-505.

Abadie, A., A. Diamond, and J. Hainmueller (2014), "Comparative Politics and the Synthetic Control Method.” American Journal of Political Science, 59(2), 495-510.

Abadie, A., and J. Gardeazabal (2003), "The Economic Costs of Conflict: A Case Study of the Basque Country." The American Economic Review, 93(1), 113-132.

Adhikari, B., R. Duval, B. Hu, and P. Loungani (2016), "Can Reform Waves Turn the Tide? Some Case Studies Using the Synthetic Control Method." IMF Working Paper 16/171.

Adler, G. and C. E. Tovar (2011) "Foreign Exchange Intervention: A Shield against Appreciation Winds?" International Monetary Fund Working Paper 11/165.

Adler, G., N. Lisack, and R. C. Mano (2015) "Unveiling the Effects of Foreign Exchange Intervention: A Panel Approach.” IMF Working Paper 15/130.

Adler, G., and R. C. Mano (2016), “The Cost of Foreign Exchange Intervention: Concepts and Measurement." IMF Working Paper 16/89.

Aizenman, J., and J. Lee (2008), "Financial versus Monetary Mercantilism: Long-run View of Large International Reserves Hoarding," The World Economy, 31, 593-611.

Alichi, A., J. Benes, J. Felman, I. Feng, C. Freedman, D. Laxton, E. Tanner, D. Vavra, and H. Wang (2015), "Frontiers of Monetary Policymaking: Adding the Exchange Rate as a Tool to Combat Deflationary Risks in the Czech Republic", IMF Working Paper 15/74.

Angrist, J. D., and J. S. Pischke (2009), Mostly Harmless Econometrics. An Empiricist's Companion, Princeton University Press.

Autor, D. (2003), "Outsourcing at Will: The Contribution of Unjust Dismissal Doctrine to the Growth of Employment Outsourcing", Journal of Labor Economics, 21(1), 1-42.

Benes, J., A. Berg, R. A. Portillo, and D. Vavra (2013), "Modeling Sterilized Interventions and Balance Sheet Effects of Monetary Policy in a New Keynesian Framework", IMF Working Paper 13/11. 
Blanchard, O., G. Adler and I. Carvalho Filho (2015), "Can Foreign Exchange Intervention Stem Exchange Rate Pressures from Global Capital Flow Shocks?” IMF Working Paper $15 / 159$.

Brůha, J., and J. Tonner, "The Exchange Rate Floor as the Instrument of Monetary Policy" The Ex-post Assessment of the Czech Experience", forthcoming CNB WP.

Cavallino, P. (2015), "Capital Flows and Foreign Exchange Intervention," mimeo.

Cavallo, E.,, S. Galiani, I. Noy, and J. Pantano (2013), “Catastrophic Natural Disasters and Economic Growth.” The Review of Economics and Statistics, 95(5), 1549-1561.

Chamon, M., M. Garcia, L. Souza (2015), "FX interventions in Brazil: a synthetic control approach", Texto Para Discussao No. 630

http://www.econ.pucrio.br/uploads/adm/trabalhos/files/td630.pdf

Clinton, K., T. Hlédik, T. Holub, D. Laxton, and H. Wang (2017), “Czech Magic:

Implementing Inflation-Forecast Targeting at the CNB”, IMF Working Paper 17/21.

Daude, C., E. Yeyati and A. Nagengast (2014), "On the Effectiveness of Exchange Rate Intervention in Emerging Markets." OECD Development Centre Working Paper 324.

Dominguez, K.M.E., F. Rasmus, and V. Pavel (2013), "Do Sales of Foreign Exchange Reserves Lead to Currency Appreciation?" Journal of Money, Credit and Banking, Volume 45, Issue 5, 867-890.

Dominguez, K., and J. A. Frankel (1990), Does Foreign Exchange Intervention Work?, No. 16 in Peterson Institute Press: All Books, Peterson Institute for International Economics.

Franta, M., T. Holub, P. Kral, I. Kubicova, K. Smidkova and B. Vasicek (2014), "The Exchange Rate as an Instrument at Zero Interest Rates: The Case of the Czech

Republic." Research and Policy Notes 2014/03, Czech National Bank, Research Department.

Gersl, A., and T. Holub (2006), "Foreign Exchange Interventions Under Inflation Targeting: The Czech Experience," Contemporary Economic Policy, Western Economic Association International 24(4), 475-491.

Ghosh, A. R., (1992): "Is it signaling? Exchange intervention and the Dollar-Deutschemark rate," Journal of International Economics, 32, 201-220.

Ghosh, A. R., J. D. Ostry, and C. G. Tsangarides (2012), "Shifting Motives: Explaining the Buildup in official Reserves in Emerging Markets Since the 1980's," IMF Working Paper 
$12 / 34$.

Heilmann, K., (2016), "Does political conflict hurt trade? Evidence from consumer boycotts." Journal of International Economics, 99, 179-191.

Iossifov, P., and J. Podpiera (2014), “Are Non-Euro Area EU Countries Importing Low Inflation from the Euro Area?” IMF Working Paper 14/191.

Jeanne, O., and R. Ranciere (2011), "The Optimal Level of International Reserves for Emerging Market Countries: A New Formula and Some Applications," The Economic Journal, 121(555), 905-930.

Kamil, H., (2008), "Is Central Bank Intervention Effective Under Inflation Targeting Regimes? The Case of Colombia," IMF Working Paper 08/88.

Krugman, P., (1998), "It's Baaack: Japan's Slump and the Return of the Liquidity Trap." Brookings Papers on Economic Activity vol. 29(2), pages 137-206.

Lizak, L., and J. Schwarz (2014), "Foreign exchange interventions as an (un)conventional monetary policy tool", BIS Papers chapters, 2013, in: Bank for International Settlements (ed.), Sovereign risk: a world without risk-free assets?, 73, 127-143

Ostry, J. D., A. R Ghosh, and M. Chamon (2012), "Two Targets, Two Instruments: Monetary and Exchange Rate Policies in Emerging Market Economies", IMF Staff Discussion Note No. $12 / 01$.

Rasmus, F., and P. Jesper (2009), "Real-time effects of central bank intervention in the euro market," Journal of International Economics 78(1), 11-20.

Rincon, H., and J. Toro (2011), "Are Capital Controls and Central Bank Intervention Effective?”, Banco de la República, Working Paper No. 625.

Sarno, L., and M. P. Taylor (2001), "Official Intervention in the Foreign Exchange Market: Is It Effective and, If So, How Does It Work?” Journal of Economic Literature 39, 839-868.

Svensson, L., (2001), "The Zero Bound in an Open Economy: A Foolproof Way of Escaping from a Liquidity Trap.” Monetary and Economic Studies 19(S-1), 277-312.

Swarnali A. H., (2016), “The Impact of Trade Agreements: New Approach, New Insights.” IMF Working Paper 16/117. 


\section{Appendix- Variables Source}

\begin{tabular}{l|l}
\hline Variable & Source \\
\hline Headline inflation & Eurostat \\
One year ahead inflation expectations & Consensus Economics \\
World commodity price inflation & IMF World Economic Outlook (WEO) \\
Unemployment rate gap & Iossifov and Podpiera (2014) from Haver and national sources \\
Contribution of taxes and administered prices & Iossifov and Podpiera (2014) from Eurostat \\
Euro Area price pressure: & Iossifov and Podpiera (2014) from Eurostat \\
Share of foreign value added in domestic demand & Iossifov and Podpiera (2014) from OECD-WTO's Trade in \\
& Value Added dataset \\
\hline
\end{tabular}

